eight Metropolitan Boroughs comprising the Administrative County of London on the night of April 26/27, 1931, numbered 4,397,003 persons. The males and females were respectively $2,044,108$ and $2,352,895$, a ratio of 1151 females per 1000 males. For the third decennium in succession, the County population shows a decline, the loss during the past intercensal period being 87,520 , a number comparable with the population of a good-sized town like Ipswich or Wigan. The number of private families has increased by $6 \cdot 17$ per cent, and the average size of the family has been reduced by 8.7 per cent, to 3.46 persons. With the reduction in the average size of the family, the average number of persons for each occupied room has declined from 1.05 in 1921 to 0.98 in 1931 ; that is to say, on an average there is less overcrowding. In Greater London, which occupies roughly a circle of 15 miles radius with Charing Cross as a centre, 8,203,942 persons were enumerated, or more than one-fifth of the total population of England and Wales.

\section{Forecasting Mortality}

IN a lecture to the Norwegian Actuarial Society printed in the Skandinavisk Aktuarietidskrift, Mr. Palin Elderton takes up the fascinating subject of forecasting mortality. Most medical statisticians and actuaries, if only for their private amusement, have tried their hands at prophecy. The most obvious line of approach, when rates of mortality in age groups are available over a long series of calendar years, is to take each group separately and to study the form of secular change, then, having more or less successfully represented the trend by some mathematical function, to extrapolate horizontally. As Mr. Elderton points out, this method would be inappropriate if changes in mortality at a later age are really determined by the experience through which the generation of which those at the later age are survivors have passed. In that case, one should consider not the horizontal but the diagonal progression of the table.

\section{Prehistoric Chronology}

AT the request of the editor of Antiquity, Mr. Miles C. Burkitt and Prof. V. Gordon Childe have prepared a chronological table of prehistory, which is published in the June number of that periodical. The progress of recent research in prehistory will secure a welcome for the chart among students, not least perhaps because of the decisive manner necessitated by its form in dealing with controversial points, which should at least be provocative of fruitful discussion. The compilers have found that a task which they anticipated would give rise to no great difficulty has proved of no little complexity. Failing the ideal method of distribution maps, it was found most practical to divide the map into several geographical areas, each of which heads a column in the list. Even so, the area of extent of specific cultures has sometimes been difficult to determine and represent. It has been found impracticable to give an absolute chronology much before 2000 B.C. In glacial chronology most of the Mousterian is taken as contemporary with Würm ii, Acheulean with Riss-Würm, and Chellean with Mindel-Riss, while pre-Chellean is definitely pre-Mindel. Even when allowance is made for local specialisation and retardation, and when a solar chronology becomes possible with the dated monuments of Egypt and Mesopotamia, difficulties have still to be overcome, as witness the correlations here put forward between Egypt and Mesopotamia, which, it is admitted, are not universally accepted. The chronological chart, with explanatory notes on each section and index, has been reprinted and is obtainable separately, price $2 s$. 6d., from the assistant editor of Antiquity, 24 Parkend Road, Gloucester.

\section{Re-opening of the South African Museum}

ON June 1 the Governor-General of the Union of South Africa, the Earl of Clarendon, opened the reconstructed South African Museum in Cape Town, and so marked the accomplishment of an instalment of the development scheme of the trustees. The Museum, founded as a Cape Government institution in 1885, was housed in a new building in 1897, but had seriously outgrown the accommodation there. The present additions permit of a running sequence in the exhibits of different sections, and have given new opportunities for the proper display of some of the treasures the Museum possesses. The additions, on two stories, consist of the old Art Gallery and an entirely new block on the opposite or Avenue side, forming two large halls, 90 feet long by about 35 feet wide. The lower of these is devoted to ethnology, and here the famous life-casts of native races have found a fitting place; the upper contains the big. game collection, and the opening is marked by the addition of a new group of springbok. The trustees and Dr. Leonard Gill have made a notable contribution to museum progress in the Union.

\section{Albinism in Wild Animals}

A VERY interesting specimen recently received at the London Zoological Gardens is a young albino reticulated python. Its eyes are pink, but the usual markings are present in orange-colour on the white skin. Albinism seems to be very rare in cold-blooded animals, but a few years ago the Gardens exhibited an albino cobra, and many years before that an albino common frog. The albino form of the axolotl, of which specimens can be seen in the aquarium, is bred in domestication like the ordinary black form, but all such specimens appear to have descended from one albino which came in the first consignment of live axolotls received in Europe during the last century. Albino or ' silver' goldfish are well known, and in the Zoological Society's aquarium can be seen white as well as golden specimens of common carp ; but these, again, are domesticated. Neither white axolotls, white goldfish, nor white carp have pink eyes, and so fall short of complete albinism. It has been noticed in birds that an albino or lutino specimen, if pink-eyed, retains its abnormal hue, but if normal-eyed, is liable to revert to type on moulting.

\section{Modifying Broadcasting Voices}

IN a broadcast talk given in America by $\mathrm{O}$. $\mathrm{H}$. Caldwell, the editor of Electronics, a method of im. proving the voices of some of the political speakers was described. By using a suitable combination of 
electrical devices in connexion with the microphone, it is possible to improve the broadcast voice by smoothing out rough and strengthening weak notes. Sounds sent over the radio can be varied by placing in the broadcasting circuit filters, compensators, and amplifiers so that the frequency and volume are permanently varied or are left to be varied at the discretion of the control engineer. High-pitched voices are transmitted much better than deep voices over the radio. It was suggested that by putting different compensators in various branches of the broadcasting networks it would be possible for a political candidate to talk with the appropriate accent in several States simultaneously.

\section{Standardisation at the Ottawa Conference}

THE question of industrial standardisation will again come before the Imperial Conference when it meets in Ottawa at the end of this month, and Mr. C. le Maistre, director of the British Standards Institution, has been appointed adviser to the delegation from Great Britain on British standards. It will be recalled that at the last two Imperial Conferences very great importance was attached to the development of inter-Empire standardisation, and to the preparation of national industrial specifications by national standardising bodies. In order to fulfil the recommendation of the last Imperial Conference, the British Engineering Standards Association recently widened its scope, and is now known as the British Standards Institution. Since last November, Mr. le Maistre has been touring the Dominions in comnexion with the development of this work.

\section{New Deposits of $\mathrm{T}$ in in the U.S.S.R.}

THE expedition of the Soviet Academy of Science under the direction of Dr. A. E. Fersman has discovered new deposits of tinstone in Tadjikistan, to the north-east of Stalinabad. The Soviet Union so far has not had its own supply of tin ore, the working of the two deposits in Transbaikalia having only just commenced. The discovery of new rich deposits of tinstone is of great importance to the national economy of the U.S.S.R., particularly in the manufacture of tins for preserved foods, in the motor tractor industry, in the production of steam engines, etc.

\section{Announcements}

The Rev. J. P. Rowland, S.J., has been appointed director of the Stonyhurst College Observatory, in succession to the Rev. E. D. O'Connor, S.J., who has been appointed rector of the College.

AT the quarterly meeting of the Royal College of Surgeons held on July 14, Sir H. J. Waring was elected president of the College in succession to Lord Moyniham. The Lister Memorial lecture of the College will be delivered by Sir Charles Ballance on April 5, 1933.

THE following officers have been elected to the Council of the Institution of Electrical Engineers for the year 1932-33, to take office on Sept. 30 :--President, Prof. E. W. Marchant; Vice-President, Mr. H. T. Young; Hon. Treasurer, Mr. P. Rosling ; Ordinary Members of Council, Prof. J. K. Catterson-Smith,
Mr. A. P. M. Fleming, Mr. H. W. H. Richards, and Mr. W. S. Burge.

AT the annual general meeting of the British Association of Research for the Cocoa, Chocolate, Sugar Confectionery, and Jam Trades, which was held on July 5, Mr. J. G. Mathieson was re-elected president and Mr. A. W. Beach and Mr. C. E. Southwell were re-elected vice-presidents.

Ir is announced that by the will of Mr. James M. G. Prophit, a sum of about $£ 120,000$ is to be divided equally for the purposes of cancer and tuberculosis research. The tuberculosis moiety has been allocated to various hospitals and colleges, including the Royal College of Physicians, and to two studentships. The cancer moiety has been allocated chiefly to the Royal College of Surgeons, the Radium Institute, the British Empire Cancer Campaign, and also to two studentships.

The ninth Annual Conference of the Association of Special Libraries and Information Bureaux will be held at Somerville College, Oxford, on Sept. 23-26. The presidential address will be delivered by Sir Charles Sherrington on Sept. 23. Among the papers to be read at the Conference are: "The Relationship between Science and the Humanities ", by Prof. J. L. Myers; "Classified Subject Indexes to Periodical Volumes", by Dr. S. C. Bradford and Prof. A. F. C. Pollard ; and "History and Sources of Official Vital Statistics", by Prof. M. Greenwood. Particulars of the Conference can be obtained from the General Secretary, Association of Special Libraries and Information Bureaux, 16 Russell Square, London, W.C.1.

Messrs. W. Heffer and Sons, Ltd., have issued a catalogue (No. 390) of publishers' 'overstocks', or 'remainders' as they are more generally termed. All books are new and are offered at about half the published price or less. We notice in the section of reference books sets of Millais" "Mammals of Great Britain and Ireland " and Thorburn's "British Mammals".

Applications are invited for the following appointments, on or before the dates mentioned :-A parttime lecturer in the Biology Department at the Plymouth and Devonport Technical College-The Secretary for Education, Education Offices, Rowe Street, Plymouth (July 23). A lecturer in mathematics at the Portsmouth Municipal College-The Registrar (July 29). A resident engineer in the Public Works Department, Hydro-Electric Branch, of the Government of the Punjab-The High Commissioner for India, General Department, India House, Aldwych, London, W.C.2 (Aug. 4). An assistant teacher of mechanical engineering and an assistant teacher in the Nautical College at the Central Technical School, Byrom Street, Liverpool-The Director of Education, 14 Sir Thomas Street, Liverpool (Aug. 8). A fulltime secretary to' the Museums Association-The Secretary, Museums Association, 39в Alfred Place, South Kensington, London (Aug. 10). A junior assistant in the Directorate of Ballistics Research, Research Department, Woolwich, S.E.18.-The Chief Superintendent. A physics laboratory assistant at the Radium Therapy Department, Duke of York Home, Bradford.

$$
\text { No. 3273, VoL. 130] }
$$

